УДК 504:619:636.2(477.42)

(C) 2013

Довгій Ю. Ю., доктор ветеринарних наук, професор,

Фещенко Д. В., кандидат ветеринарних наук,

Рябцева Н. О., Корячков В. А., асистенти, Згозінська О. А., аспірант*

Житомирський національний агроекологічний університет

\title{
ПОРІВНЯЛЬНА ЕФЕКТИВНІСТЬ ЗНЕЗАРАЖУВАННЯ ГНОЮ РІЗНИХ ВИДІВ СІЛЬСЬКОГОСПОДАРСЬКИХ ТВАРИН РЕАГЕНТАМИ ХІМІЧНОЇ ПРИРОДИ
}

\section{Рецензент - доктор ветеринарних наук А. А. Замазій}

\begin{abstract}
Наведені результати впливу різної кількості оксиду кальиію на ефективність знезаражування органічних відходів. Встановлена дезінвазійна дія розчинів хімічної природи на збудників поширених нематодозів тварин. Доведено, щзо максимальну ефективність знезараження гною досягають за температури 70-100 ${ }^{\circ} \mathrm{C}$ та теплового ефекту 120-220 кДж. Визначена висока дезінвазійна дія 1,5\%-го розчину бровадезу-20 за аскарозу свиней та $2 \%$-х кристалу-1000, ветоксу $і$ бровадезу-плюс - за стронгілятозів коней. Дезінвазійний ефект хімічних сполук щңодо збудників паразитозів залежить від концентрачії робочих розчинів.
\end{abstract}

Ключові слова: дезінвазія, тепловий ефект, гельмінти.

Постановка проблеми. Органічні відходи тваринництва - цінне добриво, проте здебільшого гній містить значну кількість патогенних мікроорганізмів і яєць гельмінтів, що створює загрозу поширення збудників інфекційних та інвазійних хвороб тварин у довкіллі. Разом із тим, враховуючи епізоотичну, санітарно-епідеміологічну та екологічну небезпеку, яку можуть створювати гній і гноєві стоки, не можна відкидати високу цінність гною 3 точки зору підвищення родючості грунтів [6]. Тому розробка нових i вдосконалення існуючих технологій знезараження, в т. ч. дезінвазії, залишається важливим екологічним і ветеринарним завданням.

Аналіз останніх досліджень i публікацій, у яких започатковано розв'язання проблеми. Здійснення ефективної дезінвазії наштовхується на чимало проблем: чітко не визначені строки дезінвазії за різних гельмінтозів тварин, збудники інвазійних хвороб швидко набувають резистентності до дії хімічних засобів, немало з яких $€$ агресивними речовинами в екологічному відношенні $[2,4]$.
Знезараження гною та дезінвазія тваринницьких приміщень із використанням сануючих препаратів хімічної природи (каустичної соди, їдкого натру, гідроксиду калію, хлориду йоду, негашеного і хлорного вапна тощо) залишається одним із найпоширеніших способів у боротьбі 3 гельмінтозами для країн СНД [5]. Із розвитком виробничих технологій, завдяки підвищенню ефективності та екологічної безпеки нових препаратів, ці заходи набувають усе більшого пріоритету.

Метою роботи було визначити ефективність реагентів різної хімічної природи на збудників паразитів.

Виходячи 3 вищевказаного, завданням наших досліджень було:

- дослідити вплив різної кількості оксиду кальцію $(\mathrm{CaO})$ на ефективність дезінвазії органічних відходів скотарства;

- встановити дезінвазійну ефективність препаратів бровадез-20 і кристал-1000 на збудників аскарозу свиней і еймеріозу кролів;

- визначити дезінвазійну ефективність розчинів кристалу- 1000 , бровадезу-плюс, ветоксу1000 за стронгілятозів коней.

Матеріали і методи дослідження. Лабораторні досліди проводили на базі Житомирської обласної державної лабораторії ветеринарної медицини та кафедри паразитології, ветеринарно-санітарної експертизи та зоогігієни ЖНАЕУ.

Перша частина досліджень передбачала вивчення процесу дезінвазії зразків гною великої рогатої худоби оксидом кальцію за стійлового безпідстилкового утримання.

Для досліду відібрали худобу, інвазовану Fasciola hepatica i Trichostrongylus sp. Впродовж п'яти годин визначали динаміку температурного

* Науковий керівник - доктор ветеринарних наук, професор Ю. Ю. Довгій 
режиму в контрольному зразку (гній без обробки $\mathrm{CaO})$ і за варіантами дезінвазії: варіант № 1 гній та вапно у співвідношенні 1:0,5; варіант № 2 - 1:0,2; варіант № 3 - 1:0,1; варіант № $4-1: 0,05$.

Друга частина досліджень полягала у визначенні ефективності застосування препаратів бровадез-20, бровадез-плюс, кристал-1000, ветокс-1000 для дезінвазії ферм проти основних нематодозів свиней і коней.

Препарати серії «Кристал» (ДНДКІ ветеринарних препаратів і кормових добавок) виготовлені на основі діальдегідів, четвертинних амонієвих солей і бігуанідину мають широкий спектр бактерицидної пролонгованої дії. Бровадез-20 і бровадез-плюс (НВФ «Бровафарма») виготовлені на основі четвертинних амонійних сполук, відзначаються широким спектром бактерицидних, вірусоцидних, фунгіцидних і нематодоцидних властивостей.

Гній $(\mathrm{n}=12)$ для дослідження був відібраний від свиней, які утримувалися на базі навчальної лабораторії тваринництва ЖНАЕУ, віком 6 міс., спонтанно уражених Ascaris suum. Для тестування препаратів використали тест-об'єкти - дерев'яні дощечки 3 окресленим квадратом $10 \times 10$ см. Проби гною наносили на поверхню квадрата тест-об'єкта, підсушували за температури $18-21{ }^{\circ} \mathrm{C}$ упродовж 15-20 хв., після чого аерозольно обробляли дезінвазійними розчинами (15 cм $\mathrm{cm}^{3}$ на кожний зразок). Кристал-1000 досліджували у концентрації 2,0 \%; бровадез-20 - 1,0 і 1,5\%.

$\mathrm{У}$ наступній частині експерименту визначали дезінвазійний вплив перелічених вище розчинів на яйця Strongylidae sp. Проби гною були відібрані від коней, спонтанно уражених стронгілятозами. Дослідження проведені на базі кінноспортивного комплексу «Алюр» с. Бистрі Житомирського району. Для визначення впливу препаратів на процес розвитку яєць зразки вносили в чашки Петрі та обприскували їх ручним пульверизатором досліджуваними розчинами $\left(20 \mathrm{~cm}^{3}\right.$ на кожну пробу). Потім чашки поміщали в термостат $\left(25-26^{\circ} \mathrm{C}\right)$ на 7 діб. Кристал-1000 досліджували у 0,3 і 2,0 \%-й концентрації, бровадез-плюс у 1,0, 2,0 \%-й, ветокс-1000 - у 0,5 і 2,0 \%-й.

У заключну частину нашої роботи був винесений дослід із визначення дезінвазійної дії бровадезу-20 і кристалу-1000 на ооцисти еймерій. Для експерименту відбирали проби фекалій кролів (n=12), інвазованих Eimeria stiedae та E. perforans. Дослідні кролі утримувались у приватних господарствах с. Глибочиця Житомирського району. Методика експерименту була аналогічною до такої у другій частині досліджень.
У групи контролю були відібрані клінічно здорові тварини.

Результативність дезінвазії оцінювали шляхом мікроскопічного дослідження тест-проб. Життездатність яєць гельмінтів оцінювали за методикою Г. А. Котельникова (1974). Видову диференціацію здійснювали за визначником «Атлас гельмінтів тварин» [1]. Культивування стронгілят органів травлення коней проводили за П. А. Величкіним [3]. Їх копроовоскопію - за методами Фюллеборна та послідовних промивань.

Результати досліджень. Для ефективного процесу термічного знезаражування органічних відходів тваринництва температурні показники мають бути вище $56^{\circ} \mathrm{C}$. Під час дезінвазії гною великої рогатої худоби оксидом кальцію термічний процес носив нестаціонарний характер.

За співвідношення гною й вапна 1:0,5 температура органо-вапнякового субстрату піднялася вище $100^{\circ} \mathrm{C}$ (тепловий ефект - 289,7 кДж), що забезпечило $100 \%$ знешкодження яєць фасціол і трихостронгілід.

У разі закладання $20 \%$ вапна від маси субстрату температура впродовж 90 хв. піднялася вище $56{ }^{\circ} \mathrm{C}$, температурний максимум досягав $80{ }^{\circ} \mathrm{C}$ і тривав 6-7 хвилин. Інтенсефективність (IE) дезінвазанта становила 97,8 \%. Якщо ж концентрації активного реагенту в складі суміші становила всього 5,0-9,0 \%, тепловий ефект сягав 57,9-28,9 кДж, температура субстрату не перевищувала $43^{\circ} \mathrm{C}$, а IE щодо трихостронгілід становила 50,0-87,5, фасціол - 85,6-95,7\%.

На рисунку відмічено наявність «плато» ефективного знезаражування, що свідчить про стійкий ефект дезінвазії за конкретно визначених умов. Так, за максимальних температур в діапазоні 70$100{ }^{\circ} \mathrm{C}$ і теплового ефекту термохімічної реакції в межах 120-220 кДж, IE знезаражування стабільно складає 96-98\%. За теплового ефекту нижче 120 кДж і максимального розігріву суміші менше $70{ }^{\circ} \mathrm{C}$ ми відмічали тенденцію до різкого спаду ефективності дезінвазії органічної компоненти гною. Досліджуючи вплив препаратів бровадез-20 і кристал-1000 на збудника аскарозу свиней було визначено, що кількість яєць $A$. suum у дослідному

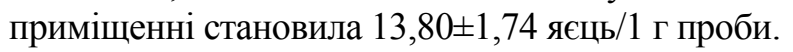

У ході використання 2,0\%-го робочого розчину кристалу- 1000 була зафіксована гомогенізація 75,0-90,0 \% яєць A. suum. Розчини 1,0 і 1,5 \%-го бровадезу-20 за експозиції 1,5 год. також проявили значний дезінвазійний ефект, про що свідчила гомогенізація 95,0-100,0 \% яєць A. suum. 


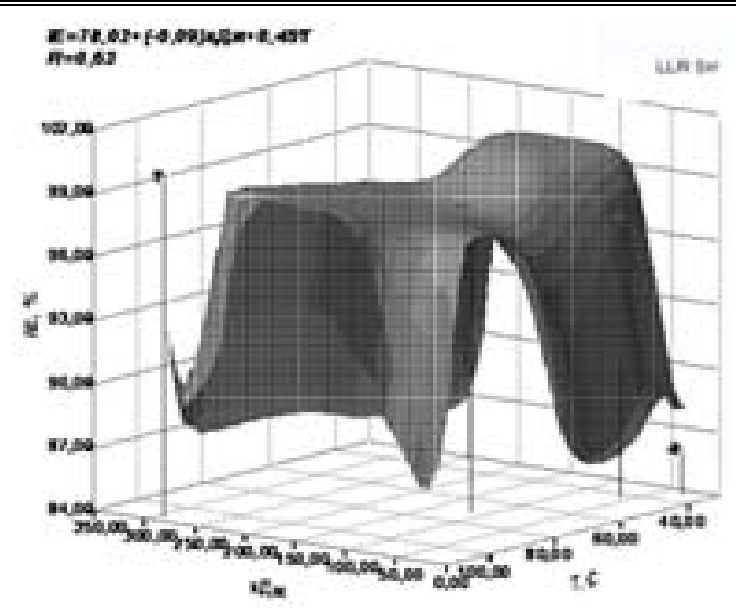

Рис. Залежність IЕ знезаражування гною СаО від тах температурного розігріву й теплового ефекту

Дезінвазійний вплив 1,0\%-го розчину бровадезу-20 за експозиції 1,25 год. на ооцисти Eimeria stiedae i E. perforans, знайдених у фекаліях дослідних кролів, сягнув 72,23\% інтенсефективності. Підвищення концентрації робочого розчину до $1,5 \%$ спричинило збільшення IE до $84,5 \%$.

Розчин 2,0 \%-го кристалу- 1000 упродовж 1,5 год. обробки фекалій кролів викликав гомогенізацію та ушкодження 72,95 \% ооцист еймерій.

За результатом експерименту щодо впливу дезінвазантів на збудників стронгілятозів коней встановлено, що обробка тест-об'єктів розчинами низької концентрації $(0,3 ; 0,5 \%)$ створювала незначний овоцидний ефект (гомогенізація 20$25 \%$ яєць). Ветокс-1000 0,5\%-й спричинив де-

\section{БІБЛІОГРАФІЯ}

1. Атлас гельмінтів тварин / І. С. Дахно, А. В. Березовський, В. Ф. Галат [та ін.]. - К. : Ветінформ, 2001. -118 c.

2. Волошина Н. О. Ветеринарний санітарнопаразитологічний моніторинг території тваринницьких господарств / Н. О. Волошина // Зб. наук. праць ЛНАУ (Ветеринарні науки). - 2007. № 7/101. - C. 87-90.

3. Котельников Г. А. Гельминтологические исследования окружающей среды / Г. А. Котельников. - М. : Госкомиздат, 1991. - 146 с.

4. Кочюмбас I. Я. Щодо розробки та вдосконалення ефективності нових дезінфекційних засобів серії «Кристал» / I. Я. Коцюмбас, О. I. Сергі$є н к о$, Л. М. Ковальчик [та ін.] // Вет. медицина формацію оболонки у 10-25 \% яєць, а у 5-10 \% іiі руйнування.

Підвищення концентрації робочих розчинів кристалу-1000, ветоксу і бровадезу-плюс до $2 \%$ (експозиція 1,5 год.) викликало гомогенізацію та деформацію оболонки 50-75 \% яєць Strongylidae spp. (кристал-900, ветокс-1000) і 75-90 \% у разі використання кристалу-1000 і бровадезу-плюс.

Досліджуючи вплив дезінвазантів на процес культивації яєць стронгілят встановлено, що дія низьких концентрацій препаратів не перешкоджала розвитку 75-90 \% яєць Strongylidae spp. до стадії личинки. Під впливом 2,0\%-го бровадезу-плюс 75,0-90,0 \% яєць стронгілят під час культивації не розвинулися до стадії личинки. Розчини кристалу-1000 і ветоксу-1000 у 2,0 \%-й концентрації викликали інактивацію 95-100 \% яєць.

\section{Висновки:}

1. Для ефективного процесу знезаражування органічних відходів тваринництва тепловий ефект повинен бути в діапазоні 120-220 кДж за максимуму розігріву суміш $80{ }^{\circ} \mathrm{C}$, що характерно для співвідношення гній-вапно 1:0,2, за вмісту оксиду кальцію $17,0 \%$ у рецептурі суміші.

2. Дезінвазійний ефект хімічних сполук щодо збудників паразитозів залежить від концентрації робочих розчинів. Для дезінвазії свинарників проти аскарозу та крільчатників проти еймеріозу рекомендуємо застосовувати кристал-1000 (2,0\%) і бровадез-20 (1,0 i 1,5\%).

3. Для боротьби зі стронгілятозами коней ефективною буде дезінвазія стаєнь $2,0 \%$-ми розчинами кристалу-1000, ветоксу-1000 та бровадезуплюс.

України. - 2007. - № 2. - С. 44.

5. Новиков Н. Л. Разработка средств и методов обеззараживания животноводческих помещений от возбудителей инвазионных и инфекционных заболеваний : автореф. дис. ... канд. вет. наук : спец. 03.00.19 «Паразитология» / Н. Л. Новиков. - М., 2004. -25 c.

6. Хом'як O. А. Проблеми утилізації, зберігання, переробки та використання відходів галузі тваринництва в Білоцерківському районі Київської області [Ел. ресурс] / О. А. Хом'як // Збірник матеріалів МНПК «Перший Всеукраїнський з'їзд екологів». - 2006. - Режим доступу: http://eco.com.ua. 